\title{
Coordination Improvement of Directional Overcurrent Relays in a Microgrid Using Modified Particle Swarm Optimization Algorithm
}

\author{
Ukwuoma Pious Akushie*, Adegboye Babatunde, Tsado Jacob \\ Department of Electrical and Electronics Engineering, Federal University of Technology, Minna, Nigeria \\ Email address: \\ piousu@gmail.com (U. P. Akushie) \\ ${ }^{*}$ Corresponding author
}

\section{To cite this article:}

Ukwuoma Pious Akushie, Adegboye Babatunde, Tsado Jacob. Coordination Improvement of Directional Overcurrent Relays in a Microgrid Using Modified Particle Swarm Optimization Algorithm. International Journal of Electrical Components and Energy Conversion.

Vol. 4, No. 1, 2018, pp. 21-32. doi: 10.11648/j.ijecec.20180401.13

Received: January 30, 2018; Accepted: February 16, 2018; Published: March 19, 2018

\begin{abstract}
An accurate and fast relaying scheme is of high importance in a radial distribution network and it becomes complex to realize in a multi-sourced distribution network with Distribution Generators (DGs). The study of the existing relay coordination of the $33 \mathrm{kV}$ Idu Industrial Park Distribution Network, Abuja and its improvement opportunities is presented in this research in other to guarantee safety of operation and protection of the distribution network against the effects of faults. A proposed 6 Bus Idu microgrid based on planned network expansion program was modeled using DIgSILENT PowerFactory software. Load Flow and Fault Analyses were performed on the modeled network to determine appropriate Directional Overcurrent Relay (DOCR) settings and a Modified Particle Swarm Optimization Algorithm (MPSO) in MATLAB environment was used to optimize the Time Dial (TD) and Pickup (PU) settings of the DOCRs. The modification adopted was to keep the solution space within boundaries so as to achieve fast convergence. The sum of the operating time of the radial feeder was found to be $3.68 \mathrm{~s}$ while that of the proposed 6 Bus Microgrid with 14 DOCRs and 3 DGs was found to be 3.7903s which was quite fast and satisfactory after validation on the modeled microgrid.
\end{abstract}

Keywords: Modified Particle Swarm Algorithm (MPSO), Microgrid, Directional Overcurrent Relays (DOCRs), Relay Coordination

\section{Introduction}

The Power situation in Nigeria has not improved despite the huge investment of the Federal Government of Nigeria. There has not been enough power made available to the DISCOs hence the need for them to start generating their own power through Embedded Generation.

Embedded Generation which is also called Distributed Generation can provide many useful services; it can provide on-site electricity in the event there is failure in the utility power supply [6].

The main objective of providing protective relays in electric power system is to ensure the fast isolation of troubled area and reducing the extent of damage to the power equipment and keeping the healthy part still in service [7]. The aim of DOCRs coordination is basically to determine the
Time Dial (TD) and Pickup Current (PU) of each relay, so as to get the total operating time of the primary relays reduced [4]. This will ensure swift isolation of the faulty section. The behavior of protection relays during fault is very critical to the safety of equipment and personnel in the power station, because the sequence of operation of the relays is governed by the coordination scheme adopted, whereas a fast algorithm will go a long way to improve coordination processes [8].

This paper presents the study of Relay Coordination practice on an existing $33 \mathrm{kV}$ radial feeder. It is envisaged that this radial feeder was modified into a 6 Bus microgrid based on proposed network expansion by the utility company. A case study of Katampe-Life Camp 33kV Feeder that is being managed by the Abuja Electricity Distribution Company (AEDC) is considered. A Modified Particle Swarm 
Optimization Algorithm (MPSO) is to be developed to provide Improved Coordination of Directional Overcurrent Relay (DOCR) of the proposed microgrid. The MPSO Algorithm will provide a solution to determine values of TD and PU settings of each DOCR which reduces the total sum of relays operating times but subject to known protection constraints [7].

Different researchers have done some work on Directional Overcurrent Relay Coordination. In the course of this research work, some reviews of related works have been sited.

In [5], a research on the Protection of Power Systems with Distributed Generation was conducted. The various ways of DG protections were x-rayed. Finally, a proposal of new approaches of DG protections was made.

A methodology based on Development of cooperative and coordinated control for distributed generation was done in [1]. This methodology was anchored on Differential Evolutionary Particle Swarm Algorithm. A Simplified Velocity Modified Particle Swam Optimization (SV-MPSO) for Directional Overcurrent relay coordination research was conducted. A Cut down approach was used to do constraint handling for DOCR coordination problem and it gave a fast convergence for a 6 bus network. The convergence speed and global optimal solution of the algorithm where found to be good when compared with its predecessors in [9]. In [2], the Big-M (penalty) method was used to optimally coordinate overcurrent relays in a distribution system. Here, a method of removing artificial variables from the objective function by using a linear programming algorithm approach written in MATLAB was used. The algorithm was successfully tested and found to give satisfactory results.

In [8], a research on optimal coordination for overcurrent relays using Particle Swarm Optimization technique and
Linear Programing technique was conducted. The algorithms were tested on 3 and 5 bus networks using MATLAB software and it was discovered to be an improvement with the Particle Swarm Optimization algorithm after comparison with Linear Programing. A Hybrid Particle Swarm Optimization Algorithm was used in [4] to optimally coordinate Directional Overcurrent Relays in a Microgrid. The Time Dial Settings was considered as continuous variable and the Pickup Current as a discrete variable. The overall coordinating time of the relays were properly minimized.

Overcurrent Relay coordination used trial-and-error approach in the past, after a while, software was introduced. Optimizing the mode of coordinating the software became a challenge. In recent years, many research works have been done on Relay coordination studies and optimal coordination of DOCRs using different optimization methods.

But none has focused on coordinating Directional Overcurrent Relays in a multi-sourced DGs network like a Combined Heat and Power (CHP) DG. Also, no work to the best of my knowledge has considered a Nigerian Industrial Area like Idu Industrial Park Abuja where large power supply is needed to meet up with huge demand capacity.

\section{Materials and Methods}

\subsection{Network Modeling and Simulation}

The 6 Bus microgrid network with Five (5) Combined Heat and Power (CHP) generators as shown in Figure 1 was modeled using DIgSILENT Powerfactory and the Load Flow, Fault Analysis and detailed system data/information of the network were properly carried out.

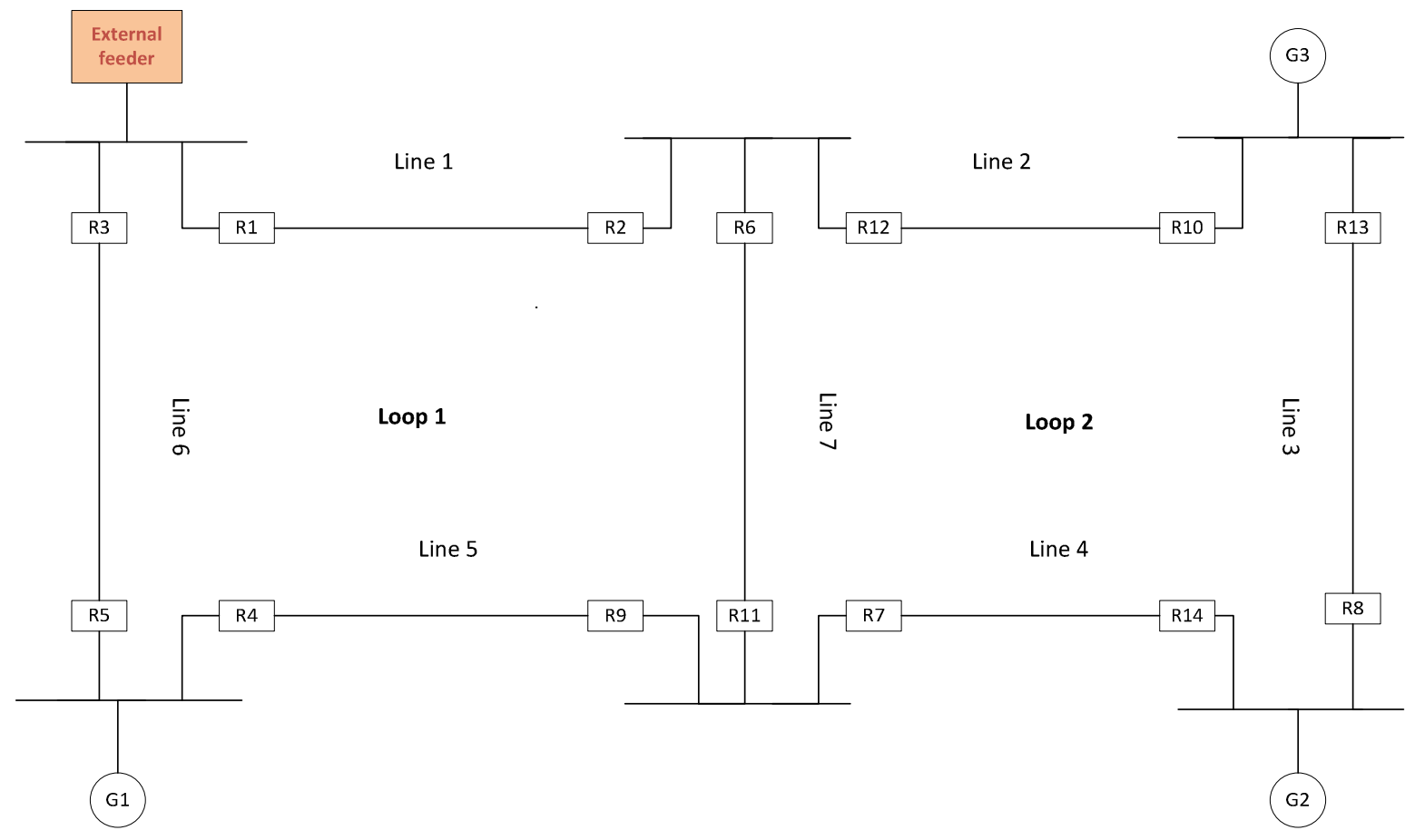

Figure 1. 6 Bus Network with 3 DGs. 
The Relays and associated equipment settings of the network were obtained and thereafter a Modified Particle Swarm Optimization Algorithm on MATLAB software was used for the optimization and coordination of the Relay settings.

Finally, the new optimized settings were tested on the modeled network to confirm relay coordination improvement. For the purpose of clarity, two different case scenarios have been considered: Case 1 and Case 2 respectively.

\subsection{Theory/Calculations}

There are two values to be set for Directional Overcurrent Relays (DOCR): The Pickup Current Setting (PU) or Plug Setting (PS) and the Time Dial Setting (TD). DOCR have an Operating Characteristic Function shown in equation 1:

$$
t_{i}=\frac{K_{1} T D}{\left(\frac{I f}{P U}\right)^{K 2}+K_{3}}
$$

where $K_{1}, K_{2}$ and $K_{3}$ are constants depending on the type of inverse time characteristic: Standard Inverse (SI), Very Inverse (VI) or Extremely Inverse (EI).

Plug Setting Multiplier $(\mathrm{PSM})=I f / P U$

Typical Inverse time characteristics of these relays are known as Standard Inverse (SI), Very Inverse (VI) and Extremely Inverse (EI).

Relay coordination problem can be solved optimally by using heuristic and meta heuristic optimization techniques [3]. It can also be solved by trial and error optimization techniques. The optimization techniques define the objective function for relay coordination by equation (2). The aim of the coordination optimization problem is to calculate the optimal values of Time Dial and Pickup current which would minimize the operating time of the primary relays (Vijayakumar et al., 2008). Minimizing the weighted sum of all the primary relays' operating time:

$$
\operatorname{MinF}=\sum_{i}^{n} W_{i} t_{i}
$$

Where,

$n$ is the number of relays,

$w_{i}$ is weight coefficient indicating the probability of fault occurrence and set as 1 ,

$t_{i}$ is the operating time of primary relay.

The objective function is minimized subject to the following constraints:

a. Coordinating Criteria

The Coordination Time Interval (CTI) must elapse before the backup protection trips. It has a mathematical expression shown in equation 3 :

$$
\mathrm{T}_{\mathrm{b}}-\mathrm{T}_{\mathrm{p}} \leq \mathrm{CTI}
$$

where $T_{b}$ is the operating time of the backup relay for a given fault in the protection zone $\mathrm{k}$. CTI may be chosen to be equal to 0.3 seconds or less.

b. Bounds on the relay setting and operating times

Upper and lower bounds are set on the TD, PU and time of operation of the relay are given in equation 3 to 6 :

$$
\begin{gathered}
T D_{i j \min } \leq T D_{i j} \leq T D_{i j \max } \\
P U_{i j \min } \leq P U_{i j} \leq P U_{i j \max } \\
T_{\text {imin }} \leq T_{i} \leq T_{\text {imax }}
\end{gathered}
$$

\subsection{Linear Programming}

This is a method used to achieve the best outcome (such as maximum profit or lowest cost) in a mathematical model whose requirements are represented by linear relationships. It is also called linear optimization.

From Equation (1), the nonlinear equation can be transformed to a linear equation as follows,

$$
t_{i}=a \cdot T D
$$

where

$$
\mathrm{a}=\frac{K_{1}}{\left(I_{f} / P U\right)^{K_{2}+K_{3}}}
$$

Objective function is as given in equation 9

$$
M i n F=\sum_{i}^{n} a . W i . T D
$$

The only variable be minimized in the objective function is TD which will now result to minimizing the operating time of the primary relays by satisfying the coordination between the primary and backup relays [10].

\subsection{Modified Particle Swarm Optimization (MPSO)}

The original PSO is modified by establishing boundaries for the optimal solution space. The main issue in the constrained optimization problem is to handle the system solution within the defined performance constraints for achieving a realistic and feasible solution. The algorithm searches the whole solution space and only keeps record of feasible solutions. Figure 2 shows the MPSO Flowchart used for the research. 


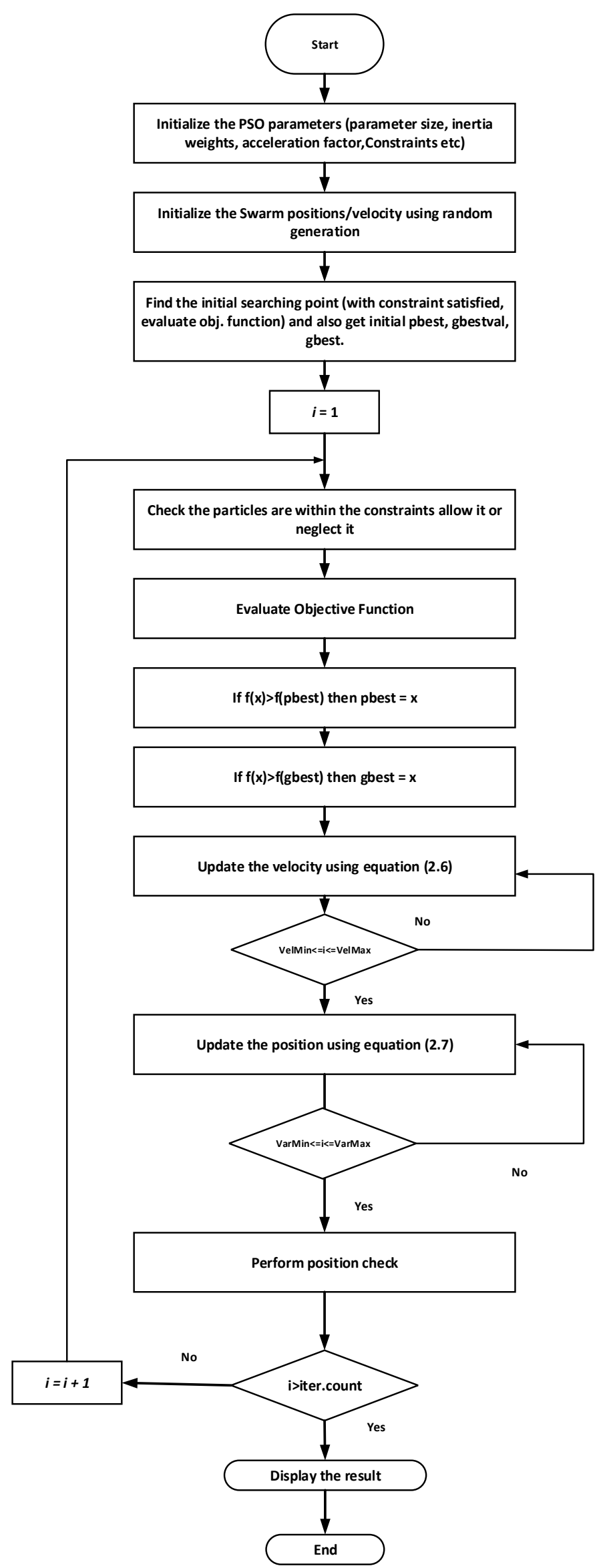

Figure 2. Flow Chart for proposed MPSO. 


\subsection{Optimal Setting of the Directional Overcurrent Relay Results Using Modified Particle Swarm Optimization Algorithm}

The optimal settings for TD and PU are obtained by invoking the MPSO algorithm on the power system relay model as stated in equation 1.

The optimization operation was done within the defined constrained in equation 4,5 and 6.

\section{Simulation Results}

After the load flow and short circuit analyses of the modeled network while making use of the data presented in Tables 1 to 4. The Result for each Feeder's Maximum current levels obtained from Load Flow study for the 6 Bus Network with 3 DGs (Microgrid) are shown in Table 5. Also, the Relay pairs with CT ratios and Fault Currents are shown in Table 6.

Table 1. Overhead Aluminum Line Data.

\begin{tabular}{llll}
\hline Line No & $\mathbf{R}(\boldsymbol{\Omega})$ & $\mathbf{X}(\boldsymbol{\Omega})$ & Length $(\mathbf{k m})$ \\
\hline 1 & 0.3675 & 3.975 & 2.5 \\
2 & 0.441 & 4.77 & 3 \\
3 & 0.3675 & 3.975 & 2.5 \\
4 & 0.22932 & 2.4804 & 1.56 \\
5 & 0.2205 & 2.385 & 1.5 \\
6 & 0.3675 & 3.975 & 2.5 \\
7 & 0.588 & 6.36 & 4 \\
\hline
\end{tabular}

Table 2. DG Data.

\begin{tabular}{llll}
\hline Bus No. & $\begin{array}{l}\text { Nominal Apparent } \\
\text { Power (MVA) }\end{array}$ & $\begin{array}{l}\text { Reactive Power } \\
\text { (MVar) }\end{array}$ & $\begin{array}{l}\text { Nominal } \\
\text { Voltage (kV) }\end{array}$ \\
\hline 6 & 6 & 0.1 & 6 \\
7 & 6 & 0.1 & 6 \\
8 & 6 & 0.1 & 6 \\
\hline
\end{tabular}

Table 3. Transformer Data.

\begin{tabular}{llll}
\hline Bus to Bus & Rated Power (MVA) & Vp (kV) & Vs (kV) \\
\hline $5-8$ & 6 & 6 & 33 \\
$3-7$ & 6 & 6 & 33 \\
$2-6$ & 6 & 6 & 33 \\
\hline
\end{tabular}

Table 4. Load Data.

\begin{tabular}{lll}
\hline Bus No. & Real Power (MW) & Reactive Power (MVar) \\
\hline 1 & 1.5 & -1.125 \\
2 & 3.0 & -2.25 \\
3 & 0.5 & -0.325 \\
4 & 0.5 & 0.325 \\
5 & 3 & 2.25 \\
6 & 5 & 3.25 \\
\hline
\end{tabular}

Table 5. Maximum Current on Each Line.

\begin{tabular}{ll}
\hline Feeder Line & Maximum Load Current (kA) \\
\hline 1 & 0.026 \\
2 & 0.047 \\
3 & 0.036 \\
4 & 0.056 \\
5 & 0.007 \\
6 & 0.084 \\
7 & 0.037 \\
\hline
\end{tabular}

Table 6. Primary/Backup Relay Pairs for 6 Bus Faults.

\begin{tabular}{lllll}
\hline $\begin{array}{l}\text { Backup } \\
\text { Relay }\end{array}$ & $\begin{array}{l}\text { Fault Current } \\
\text { (kA) }\end{array}$ & $\begin{array}{l}\text { Primary } \\
\text { Relay }\end{array}$ & $\begin{array}{l}\text { Fault Current } \\
\text { (kA) }\end{array}$ & CT Ratio \\
\hline R1 & 5.049 & R6 & 1.431 & $300: 1$ \\
R1 & 5.049 & R12 & 1.100 & $300: 1$ \\
R2 & 0.573 & R3 & 0.683 & $300: 1$ \\
R6 & 1.695 & R7 & 1.429 & $300: 1$ \\
R6 & 1.695 & R9 & 3.375 & $300: 1$ \\
R12 & 2.339 & R13 & 1.862 & $300: 1$ \\
R10 & 1.100 & R2 & 5.049 & $300: 1$ \\
R10 & 1.100 & R6 & 1.431 & $300: 1$ \\
R13 & 1.602 & R14 & 2.961 & $300: 1$ \\
R8 & 1.862 & R10 & 2.339 & $300: 1$ \\
R14 & 1.429 & R9 & 3.375 & $300: 1$ \\
R14 & 1.429 & R11 & 1.695 & $300: 1$ \\
R7 & 2.961 & R8 & 1.602 & $300: 1$ \\
R11 & 1.431 & R2 & 5.049 & $300: 1$ \\
R11 & 1.431 & R12 & 1.100 & $300: 1$ \\
R9 & 2.274 & R5 & 5.047 & $300: 1$ \\
R4 & 3.375 & R7 & 1.429 & $300: 1$ \\
R4 & 3.375 & R11 & 1.695 & $300: 1$ \\
R5 & 0.683 & R1 & 0.573 & $300: 1$ \\
R3 & 5.047 & R4 & 2.274 & \\
\hline & & & & $300: 1$ \\
\hline
\end{tabular}

The optimized settings for the TD and PU of the relays using MPSO are shown in Table 7 and the Existing KatampeLife Camp 33kV Feeder Overcurrent Relay settings before optimization are shown in Table 8 while the Protection Settings (Overcurrent) after optimization are shown in Table 9. Figures 4 to 7 and Figures 9 to 12 shows the TimeOvercurrent graphs for the DOCRs using the optimized relay settings.

Table 7. Optimal Values of TD and PU using MPSO.

\begin{tabular}{|c|c|c|c|c|c|}
\hline Relay No. & TD (s) & PU & Relay No. & TD (s) & $\mathbf{P U}$ \\
\hline 1 & 0.7414 & 0.8 & 8 & 0.5082 & 1.0 \\
\hline 2 & 0.3546 & 0.8 & 9 & 0.2671 & 0.8 \\
\hline 3 & 0.9232 & 1.0 & 10 & 0.7543 & 1.0 \\
\hline 4 & 0.5931 & 0.5 & 11 & 0.3815 & 1.0 \\
\hline 5 & 0.6856 & 0.5 & 12 & 0.5395 & 1.0 \\
\hline 6 & 1.0283 & 1.0 & 13 & 0.4727 & 0.5 \\
\hline 7 & 0.7153 & 0.5 & 14 & 0.1000 & 1.5 \\
\hline \multicolumn{2}{|c|}{ Objective Function $(\mathrm{T})$} & $3.7903 \mathrm{~s}$ & & & \\
\hline
\end{tabular}


Table 8. Overcurrent Relay Setting Parameters before optimization.

\begin{tabular}{llllllllll}
\hline S/N & Protective Device & Location & Stage Phase & Current (Prim A & Current Sec A) & Current (p.u) & TD (S) & Characteristics & Direction \\
\hline 1 & Relay 1 (Katampe) & Bus 1 & $\mathrm{I}>\mathrm{t}$ & 450 & 0.75 & 0.75 & 0.5 & Inverse & None \\
2 & & & $\mathrm{I}>\mathrm{t}$ & 2000 & 0.30 & 0.30 & 0.02 & Definite & None \\
3 & Relay 2 (Life Camp) & Bus 2 & $\mathrm{I}>\mathrm{t}$ & 450 & 0.75 & 0.75 & 0.52 & Inverse & None \\
4 & & & $\mathrm{I}>>\mathrm{t}$ & 1750 & 0.34 & 0.34 & 0.02 & Definit & None \\
\hline
\end{tabular}

Table 9. Protection Settings (Overcurrent) after optimization.

\begin{tabular}{|c|c|c|c|c|c|c|c|c|c|c|c|c|}
\hline & $\begin{array}{l}\text { Protection } \\
\text { Device }\end{array}$ & Location & Branch & Manufacturer & Model & $\begin{array}{l}\text { Stage } \\
\text { (Pha se) }\end{array}$ & $\begin{array}{l}\text { Current } \\
\text { [pri. A] }\end{array}$ & $\begin{array}{l}\text { Current } \\
\text { [sec. A] }\end{array}$ & $\begin{array}{l}\text { Current } \\
\text { [p. u.] }\end{array}$ & $\begin{array}{l}\text { Tim } \\
\text { e }\end{array}$ & Characteristic & $\begin{array}{l}\text { Direction } \\
\text { al }\end{array}$ \\
\hline 1 & R1 & $\begin{array}{l}\text { Single } \\
\text { Busbar/BUS } 1\end{array}$ & Line 1 & Generic & $\begin{array}{l}\text { Rel-Toc- } \\
\text { Dirextst }\end{array}$ & Toc & 240.00 & 0.80 & 0.80 & 0.74 & $\begin{array}{l}\text { IEC 255-3 } \\
\text { inverse }\end{array}$ & $\begin{array}{l}\text { Directiona } \\
1\end{array}$ \\
\hline 2 & $\mathrm{R} 3$ & $\begin{array}{l}\text { Single } \\
\text { Busbar/BUS } 1\end{array}$ & Line 6 & Generic & $\begin{array}{l}\text { Rel-Toc- } \\
\text { Dirextst }\end{array}$ & Toc & 300.00 & 1.00 & 1.00 & 0.92 & $\begin{array}{l}\text { IEC 255-3 } \\
\text { inverse }\end{array}$ & $\begin{array}{l}\text { Directiona } \\
1\end{array}$ \\
\hline 3 & R12 & $\begin{array}{l}\text { Single Busbar } \\
\text { (1)/BUS } 2\end{array}$ & Line 2 & Generic & $\begin{array}{l}\text { Rel-Toc- } \\
\text { Dirextst }\end{array}$ & Toc & 300.00 & 1.00 & 1.00 & 0.54 & $\begin{array}{l}\text { IEC 255-3 } \\
\text { inverse }\end{array}$ & $\begin{array}{l}\text { Directiona } \\
1\end{array}$ \\
\hline 4 & $\mathrm{R} 2$ & $\begin{array}{l}\text { Single Busbar } \\
\text { (1)/BUS } 2\end{array}$ & Line 1 & Generic & $\begin{array}{l}\text { Rel-Toc- } \\
\text { Dirextst }\end{array}$ & Toc & 240.00 & 0.80 & 0.80 & 0.35 & $\begin{array}{l}\text { IEC 255-3 } \\
\text { inverse }\end{array}$ & $\begin{array}{l}\text { Directiona } \\
1\end{array}$ \\
\hline 5 & R6 & $\begin{array}{l}\text { Single Busbar } \\
\text { (1)/BUS } 2\end{array}$ & Line 7 & Generic & $\begin{array}{l}\text { Rel-Toc- } \\
\text { Dirextst }\end{array}$ & Toc & 300.00 & 1.00 & 1.00 & 1.03 & $\begin{array}{l}\text { IEC 255-3 } \\
\text { inverse }\end{array}$ & $\begin{array}{l}\text { Directiona } \\
1\end{array}$ \\
\hline 6 & R10 & $\begin{array}{l}\text { Single Busbar } \\
\text { (2)/BUS } 3\end{array}$ & Line 2 & Generic & $\begin{array}{l}\text { Rel-Toc- } \\
\text { Dirextst }\end{array}$ & Toc & 300.00 & 1.00 & 1.00 & 0.75 & $\begin{array}{l}\text { IEC 255-3 } \\
\text { inverse }\end{array}$ & $\begin{array}{l}\text { Directiona } \\
1\end{array}$ \\
\hline 7 & R13 & $\begin{array}{l}\text { Single Busbar } \\
\text { (2)/BUS } 3\end{array}$ & Line 3 & Generic & $\begin{array}{l}\text { Rel-Toc- } \\
\text { Dirextst }\end{array}$ & Toc & 150.00 & 0.50 & 0.50 & 0.47 & $\begin{array}{l}\text { IEC 255-3 } \\
\text { inverse }\end{array}$ & $\begin{array}{l}\text { Directiona } \\
1\end{array}$ \\
\hline 8 & R4 & $\begin{array}{l}\text { Single Busbar } \\
\text { (3)/BUS } 6\end{array}$ & Line 5 & Generic & $\begin{array}{l}\text { Rel-Toc- } \\
\text { Dirextst }\end{array}$ & Toc & 150.00 & 0.50 & 0.50 & 0.59 & $\begin{array}{l}\text { IEC 255-3 } \\
\text { inverse }\end{array}$ & $\begin{array}{l}\text { Directiona } \\
1\end{array}$ \\
\hline 9 & R5 & $\begin{array}{l}\text { Single Busbar } \\
\text { (3)/BUS } 6\end{array}$ & Line 6 & Generic & $\begin{array}{l}\text { Rel-Toc- } \\
\text { Dirextst }\end{array}$ & Toc & 150.00 & 0.50 & 0.50 & 0.69 & $\begin{array}{l}\text { IEC 255-3 } \\
\text { inverse }\end{array}$ & $\begin{array}{l}\text { Directiona } \\
1\end{array}$ \\
\hline 10 & R11 & $\begin{array}{l}\text { Single Busbar } \\
\text { (4)/BUS } 5\end{array}$ & Line 7 & Generic & $\begin{array}{l}\text { Rel-Toc- } \\
\text { Dirextst }\end{array}$ & Toc & 300.00 & 1.00 & 1.00 & 0.38 & $\begin{array}{l}\text { IEC 255-3 } \\
\text { inverse }\end{array}$ & $\begin{array}{l}\text { Directiona } \\
1\end{array}$ \\
\hline 11 & R7 & $\begin{array}{l}\text { Single Busbar } \\
\text { (4)/BUS } 5\end{array}$ & Line 4 & Generic & $\begin{array}{l}\text { Rel-Toc- } \\
\text { Dirextst }\end{array}$ & Toc & 150.00 & 0.50 & 0.50 & 0.72 & $\begin{array}{l}\text { IEC 255-3 } \\
\text { inverse }\end{array}$ & $\begin{array}{l}\text { Directiona } \\
1\end{array}$ \\
\hline 12 & R9 & $\begin{array}{l}\text { Single Busbar } \\
\text { (4)/BUS } 5\end{array}$ & Line 5 & Generic & $\begin{array}{l}\text { Rel-Toc- } \\
\text { Dirextst }\end{array}$ & Toc & 240.00 & 0.80 & 0.80 & 0.26 & $\begin{array}{l}\text { IEC 255-3 } \\
\text { inverse }\end{array}$ & $\begin{array}{l}\text { Directiona } \\
1\end{array}$ \\
\hline 13 & R14 & $\begin{array}{l}\text { Single Busbar } \\
\text { (5)/BUS } 4\end{array}$ & Line 4 & Generic & $\begin{array}{l}\text { Rel-Toc- } \\
\text { Dirextst }\end{array}$ & Toc & 450.00 & 1.50 & 1.50 & 0.10 & $\begin{array}{l}\text { IEC 255-3 } \\
\text { inverse }\end{array}$ & $\begin{array}{l}\text { Directiona } \\
1\end{array}$ \\
\hline 14 & R8 & $\begin{array}{l}\text { Single Busbar } \\
\text { (5)/BUS } 4\end{array}$ & Line 3 & Generic & $\begin{array}{l}\text { Rel-Toc- } \\
\text { Dirextst }\end{array}$ & Toc & 300.00 & 1.00 & 1.00 & 0.50 & $\begin{array}{l}\text { IEC 255-3 } \\
\text { inverse }\end{array}$ & $\begin{array}{l}\text { Directiona } \\
1\end{array}$ \\
\hline
\end{tabular}

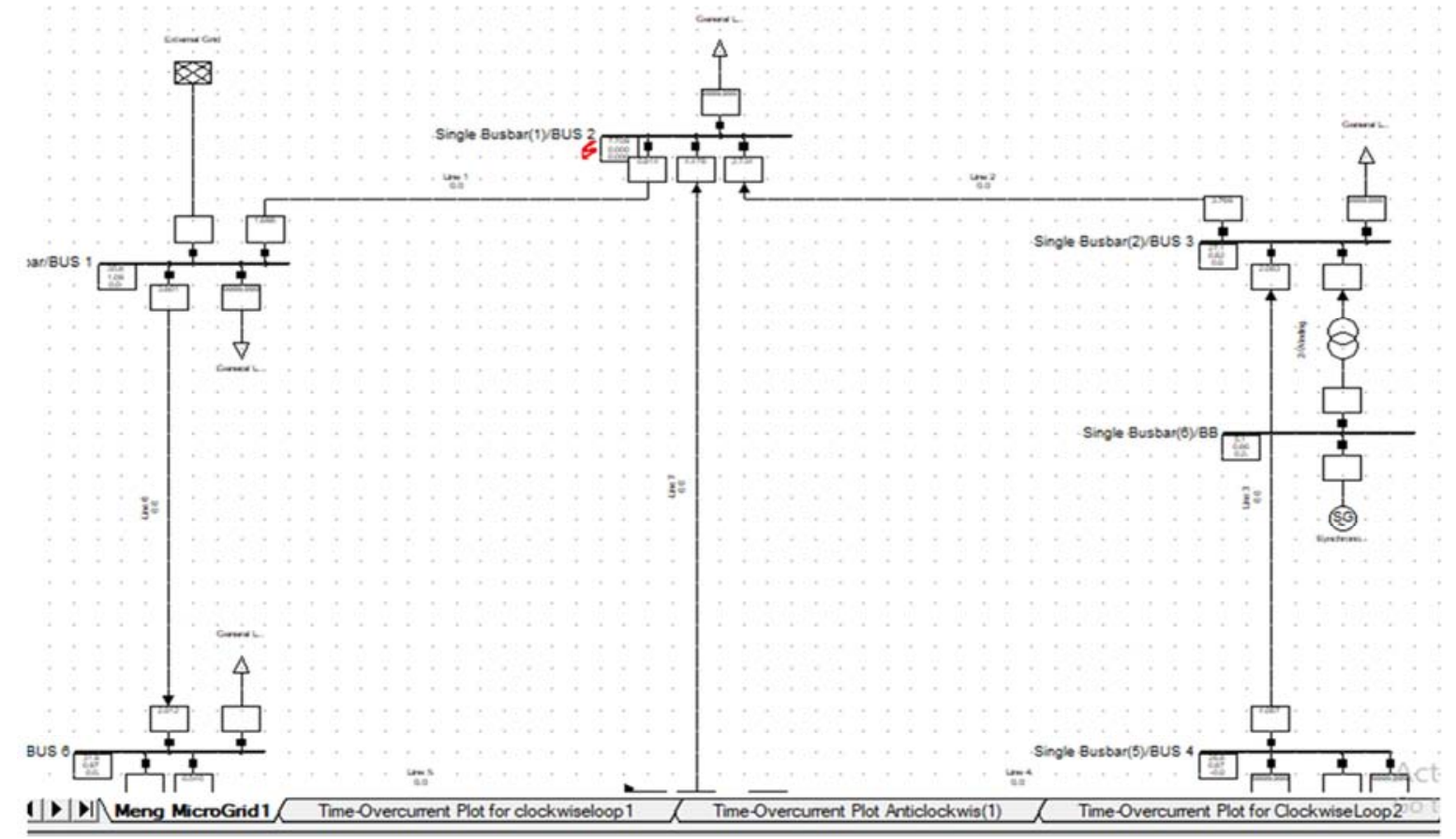

Figure 3. Network with Fault on Single Busbar 2: 


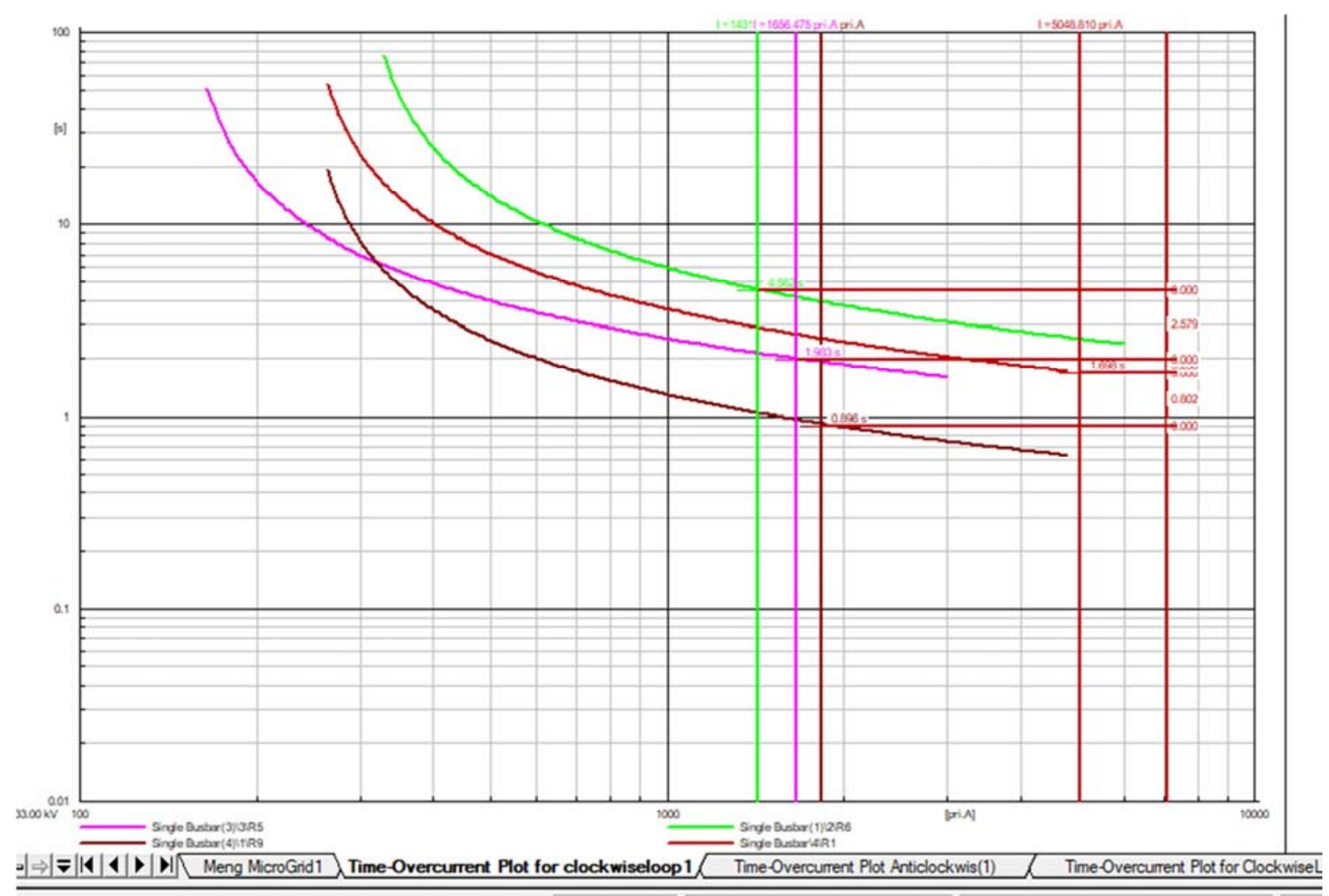

Figure 4. Time-Overcurrent Characteristics for Clockwise Loop1.

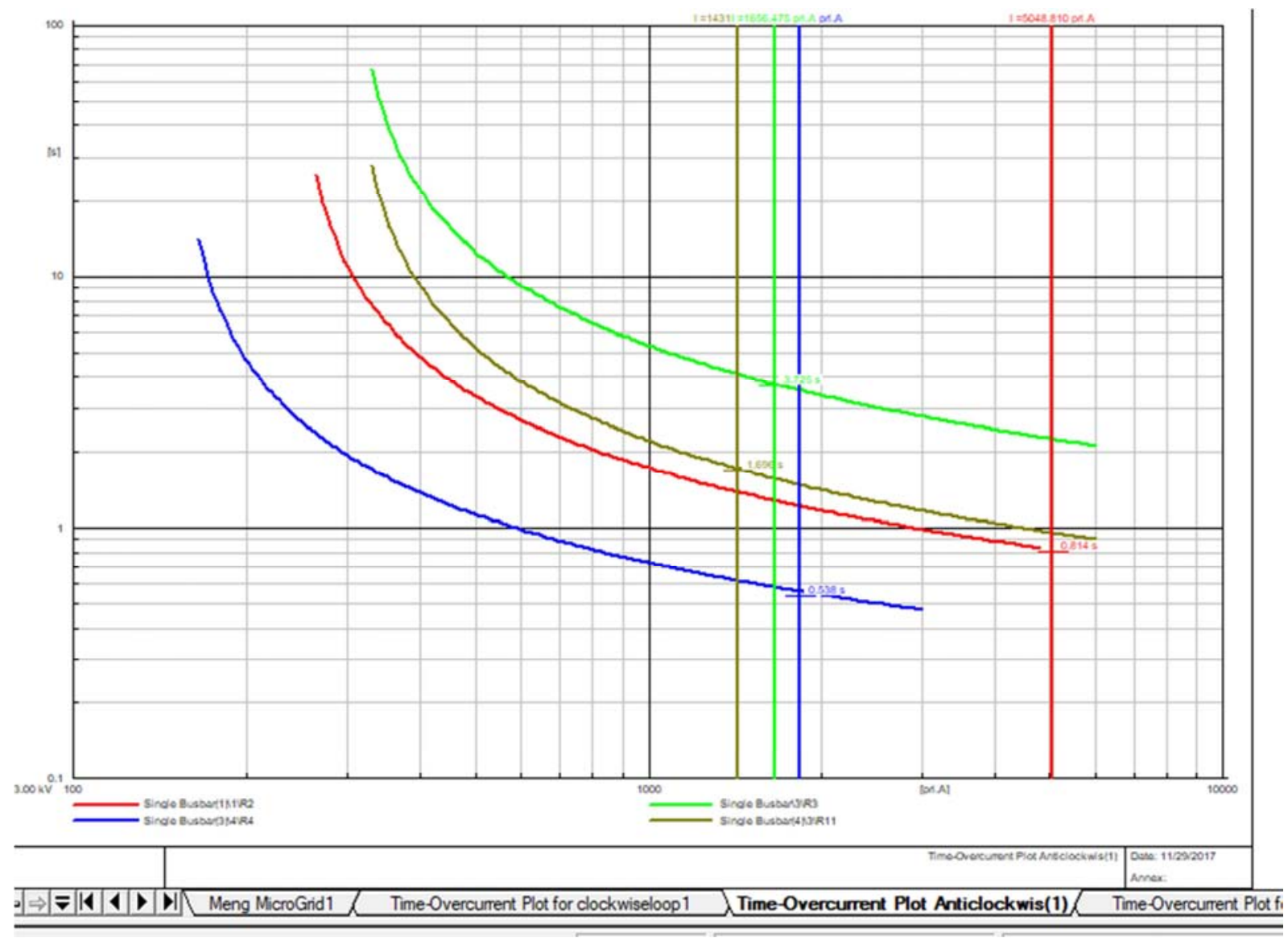

Figure 5. Time-Overcurrent Characteristics for Anticlockwise Loop1. 


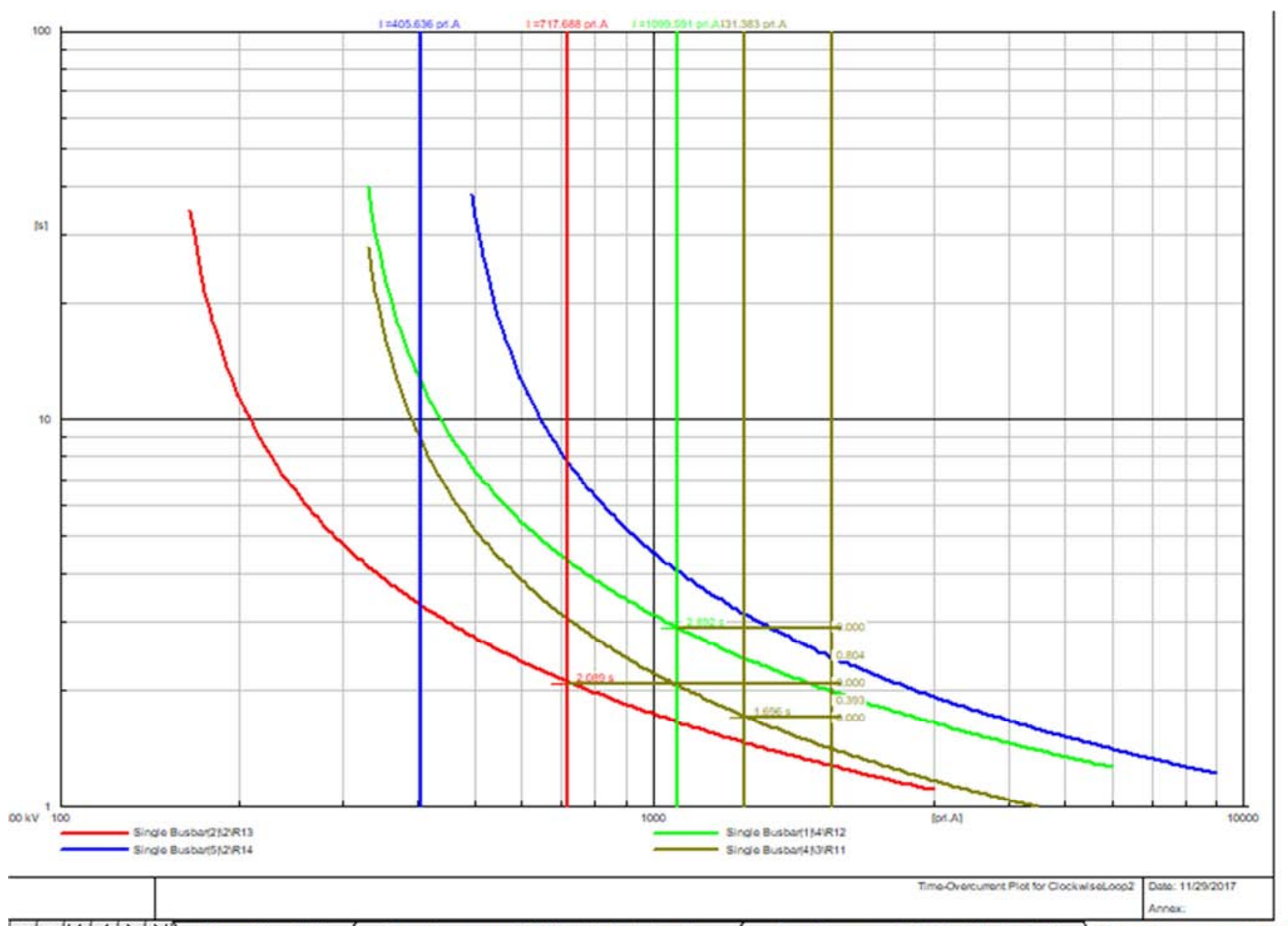

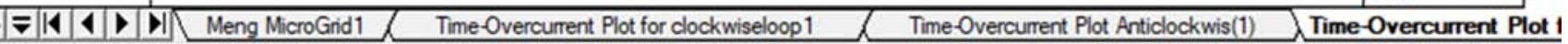

Figure 6. Time-Overcurrent Characteristics for Clockwise Loop2.

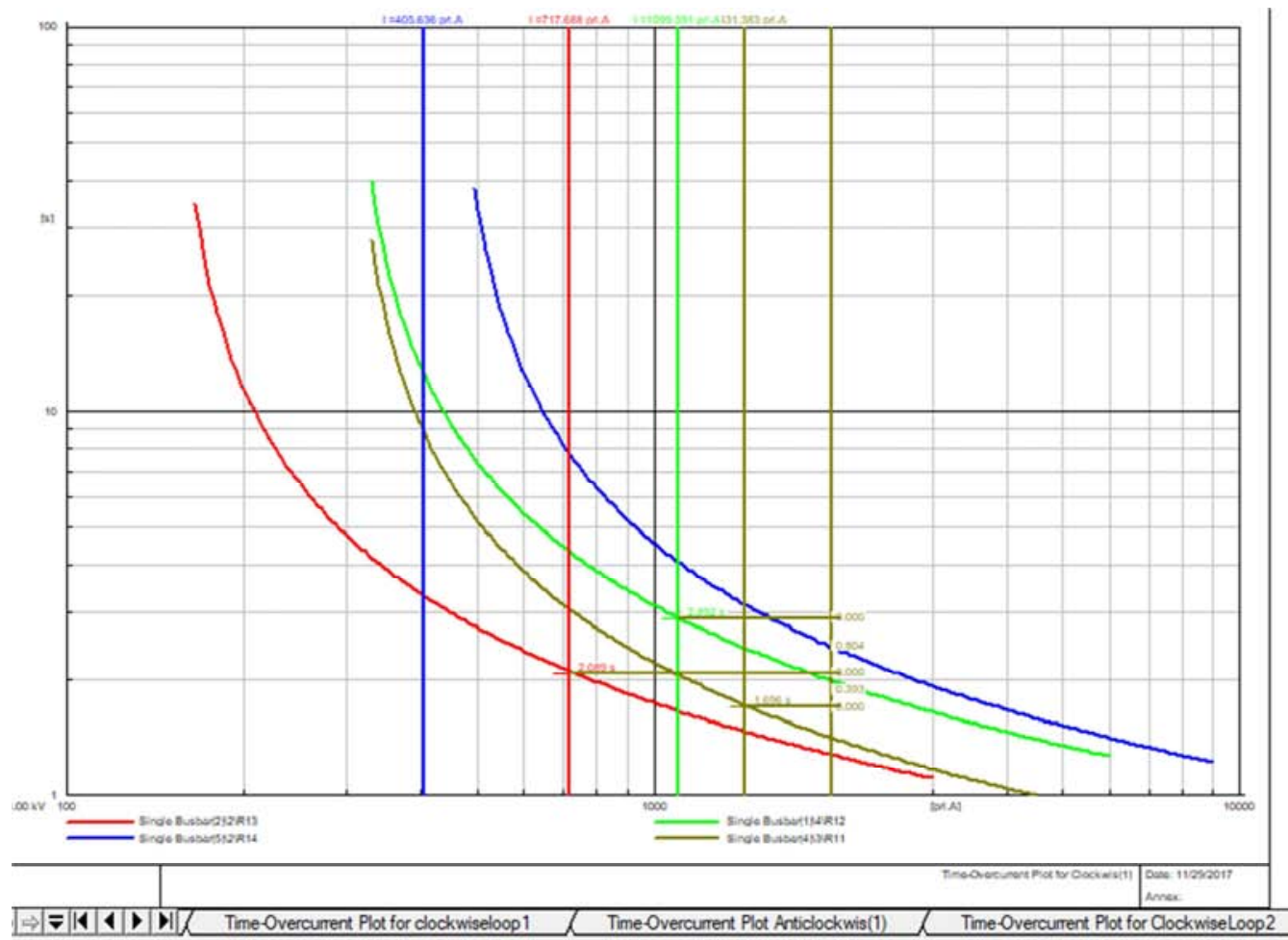

Figure 7. Time-Overcurrent Characteristics for Anticlockwise Loop2. 


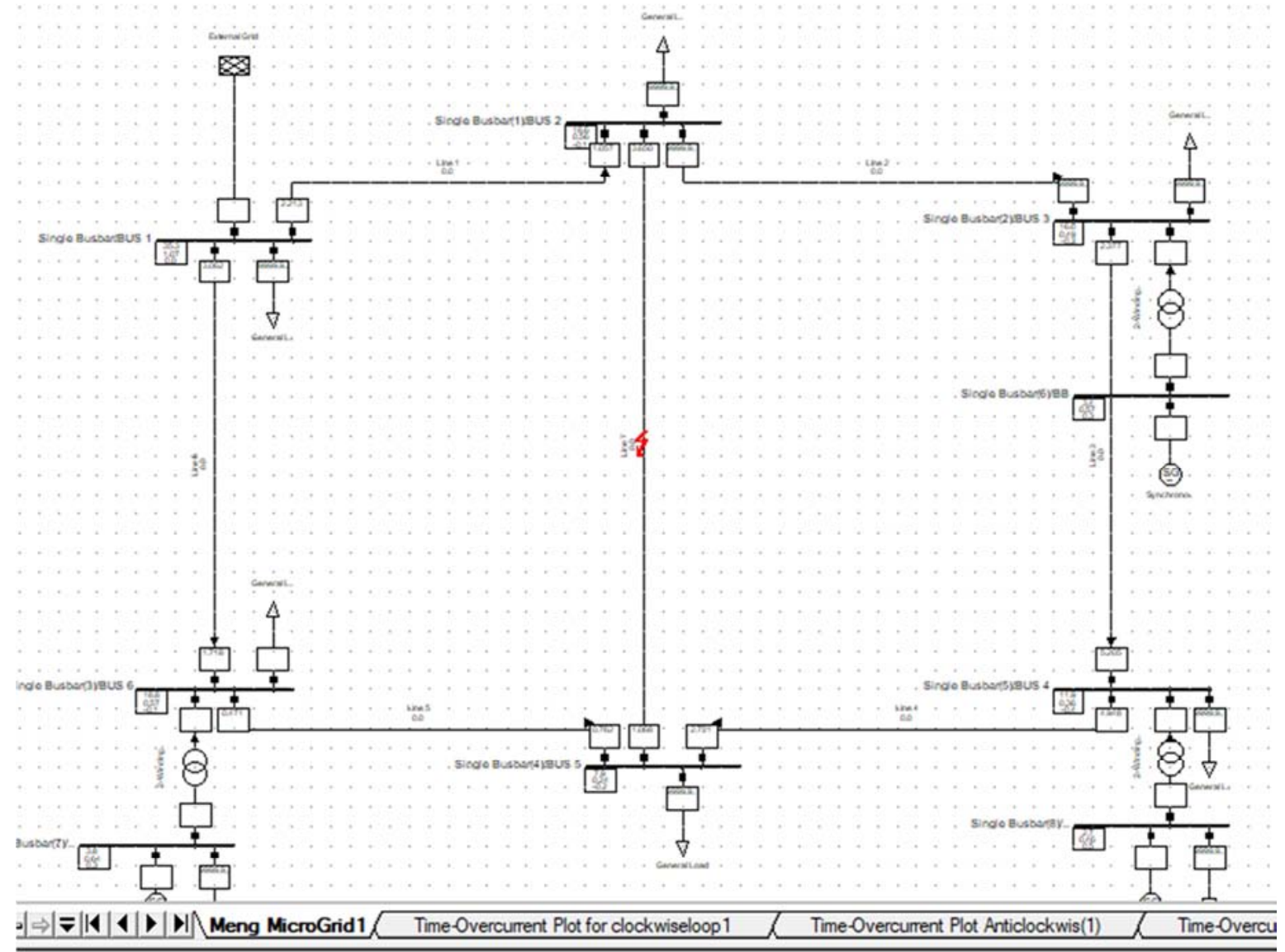

Figure 8. Network with Fault on Line7.

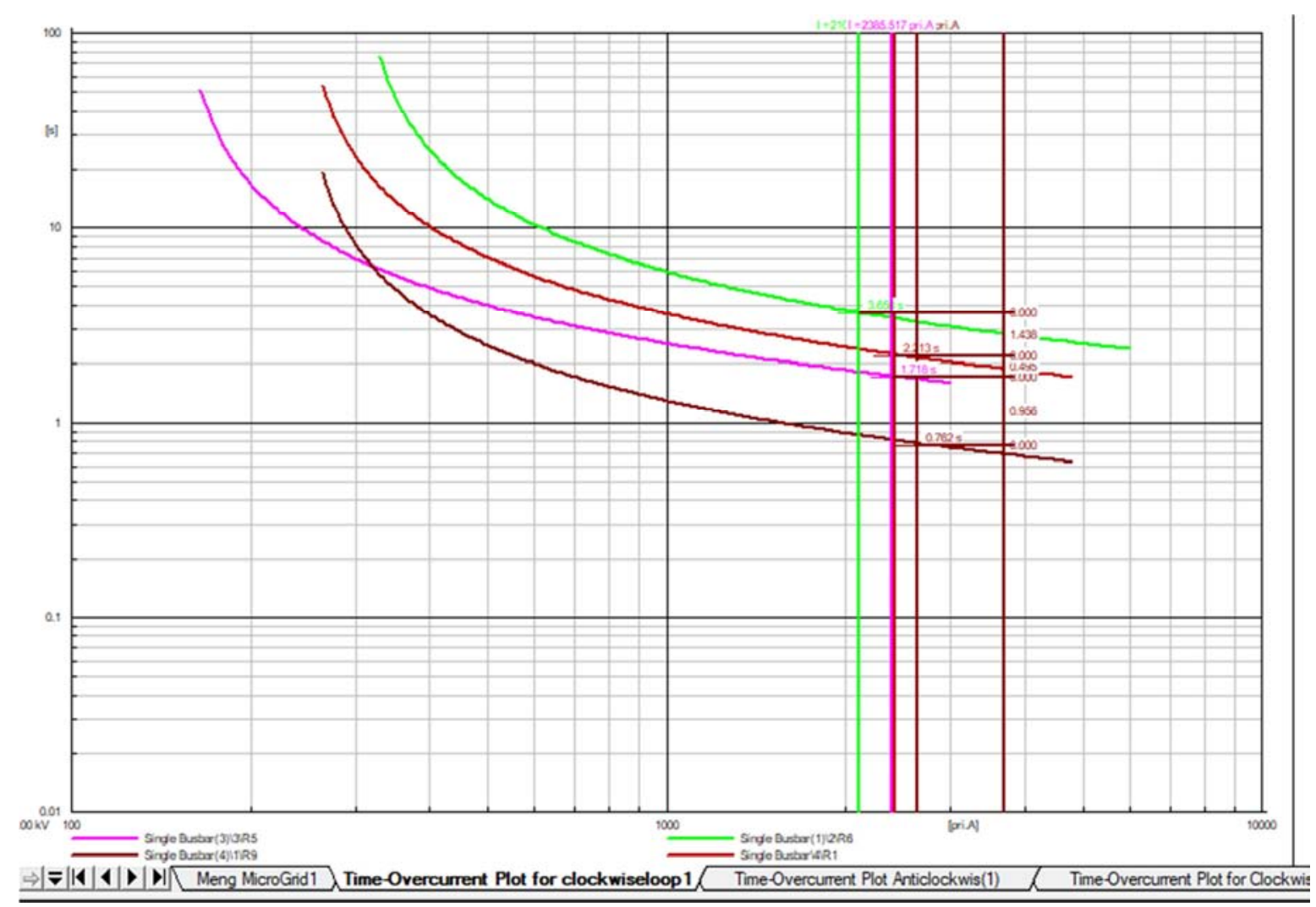

Figure 9. Time-Overcurrent Characteristics for Clockwise Loop1. 


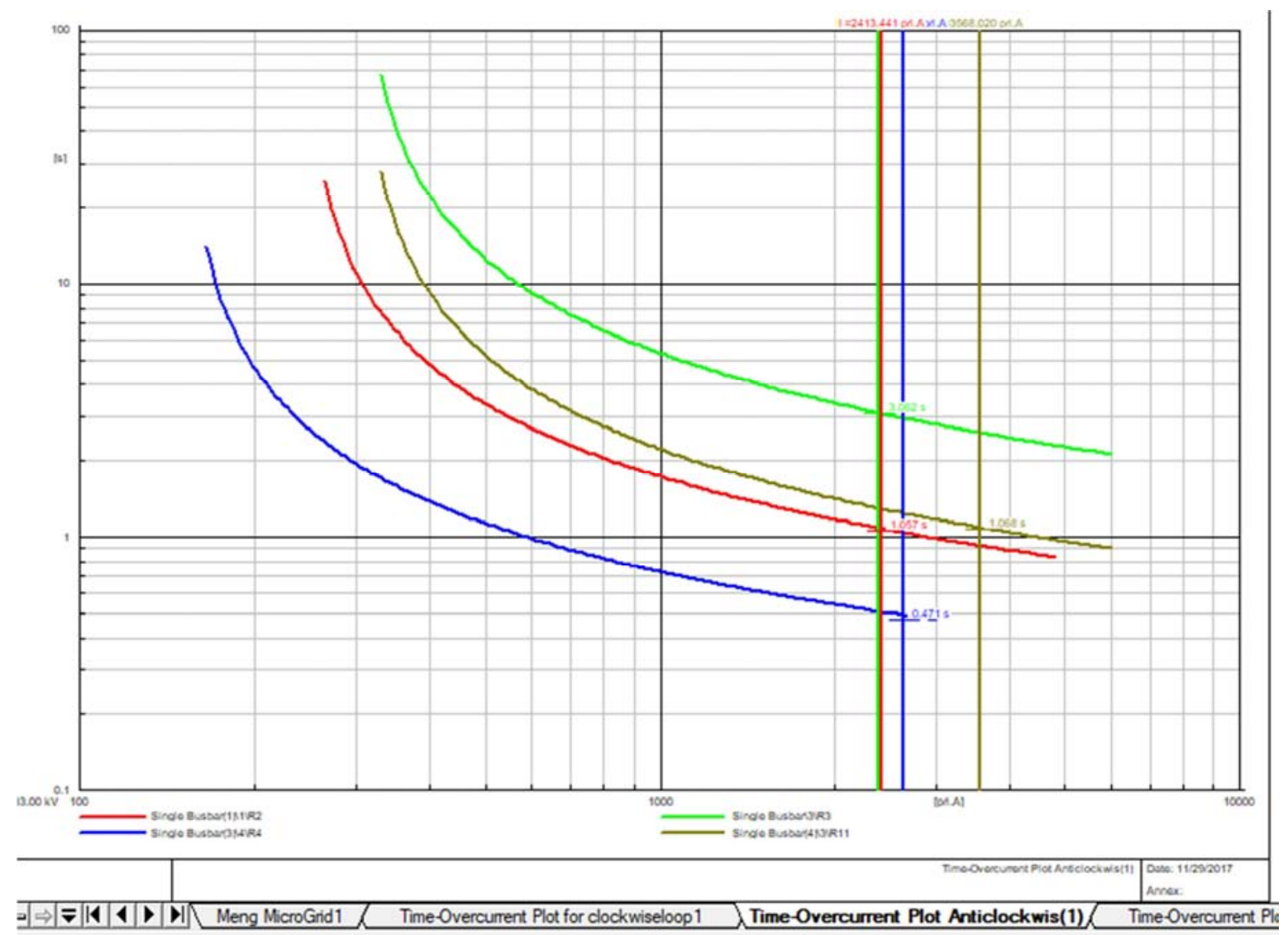

Figure 10. Time-Overcurrent Characteristics for Anticlockwise Loop1.

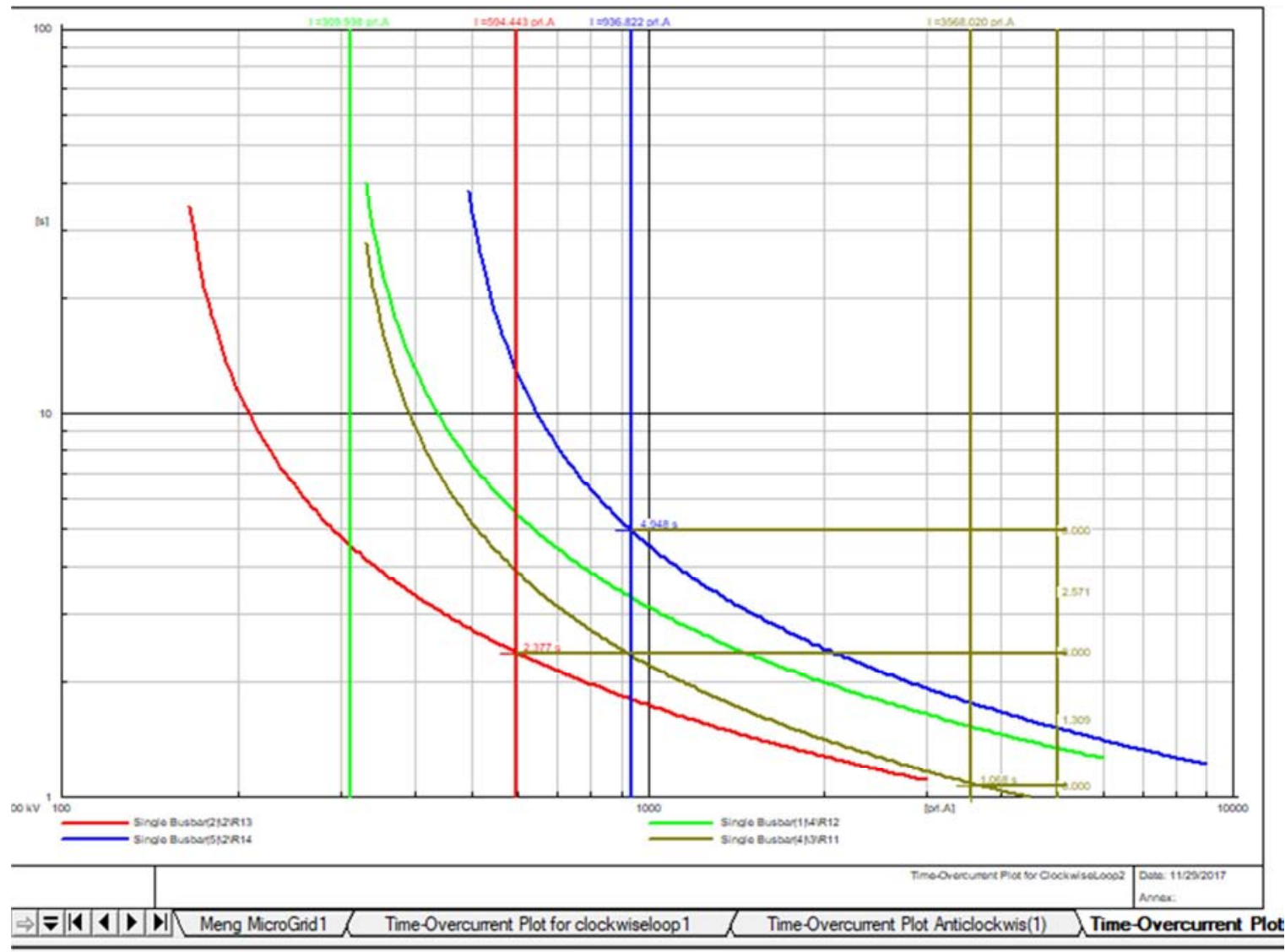

Figure 11. Time-Overcurrent Characteristics for Clockwise Loop2. 


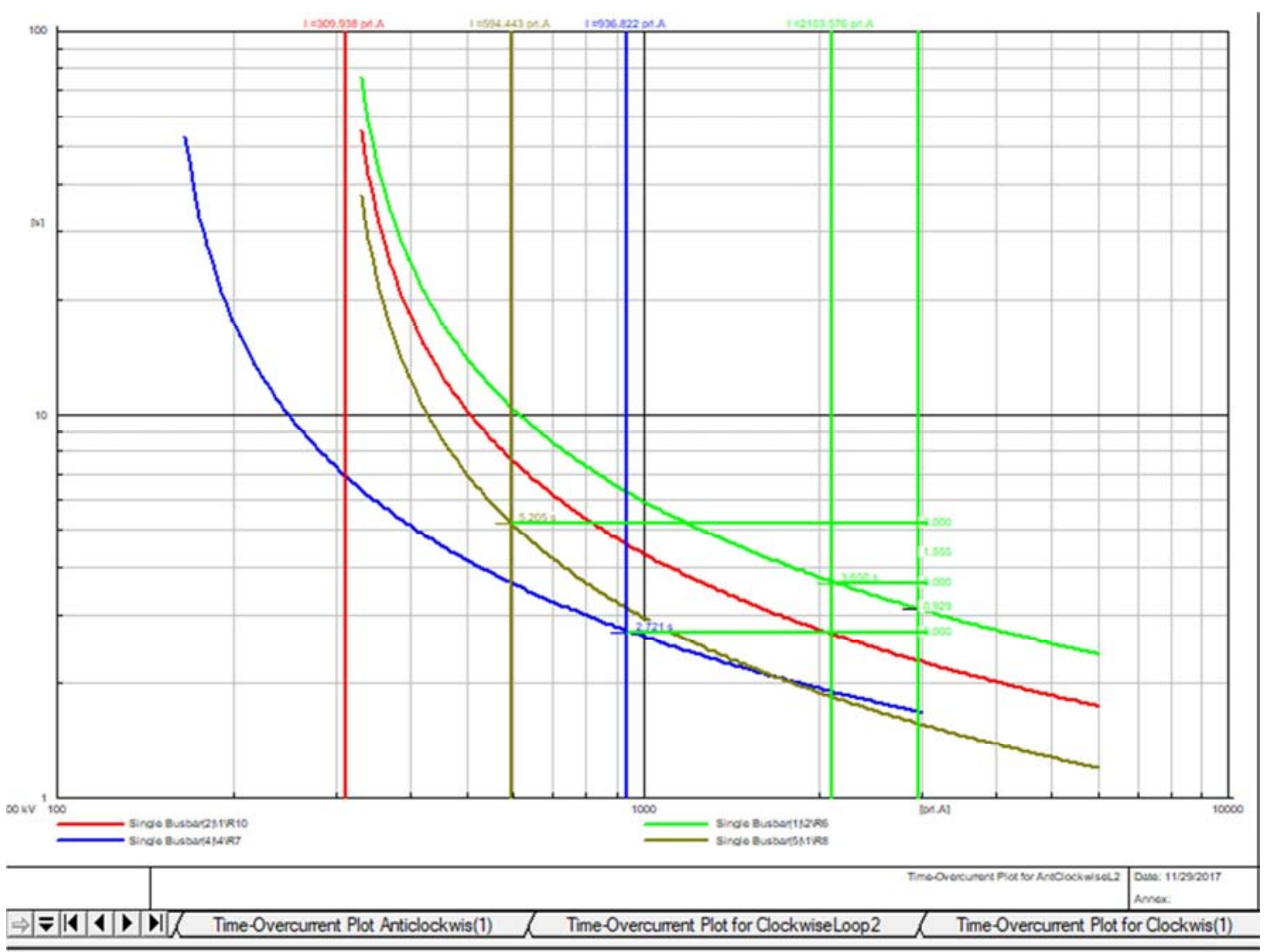

Figure 12. Time-Overcurrent Characteristics for Anticlockwise Loop2.

\section{Discussions}

The results obtained from the proposed MPSO Algorithm displayed in Table 7 shows an improvement in the overall tripping timing of the relays. The optimal tripping time of all the primary relays of the 6 Bus microgrid comprising of 14 DOCRs was $3.7903 \mathrm{~s}$ while that obtained for the existing Katempe-Life Camp feeder for just 2 relays was 3.68s. Using the optimized Relay settings to run fault studies on Line 7 and Single Busbar 2 gave various tripping times for both Clockwise Looping and Anticlockwise Looping Relay coordination as shown in Figures 3 to Figures 12. Table 8 and 9 shows the Relay settings before and after optimization respectively.

\subsection{Fault on Single Busbar 2}

For a multi-loop network, Relay coordination is implemented in clockwise and anti-clockwise sequence by use of directional overcurrent relays.

From Figure 4: The Time-Overcurrent Characteristics for Clockwise Loop1, the Coordination sequence is as follows: R9 trips at $0.901 \mathrm{~s}$ while R1 follows at $1.698 \mathrm{~s}$ if R9 failed to trip, then R5 trips at 2.012s, finally, R6 trips at $4.178 \mathrm{~s}$.

From Figure 5: The Time-Overcurrent Characteristics for AntiClockwise Loop1, the Coordination sequence is as follows: R4 trips at $0.540 \mathrm{~s}$ while $\mathrm{R} 2$ follows at $0.814 \mathrm{~s}$ if $\mathrm{R} 4$ fails to trip, then R11 trips at 1.565 , finally, R3 trips at $3.801 \mathrm{~s}$.
From Figure 6: The Time-Overcurrent Characteristics for Clockwise Loop2, the Coordination sequence is as follows: R11 trips at 1.665 s followed by R13 at 2.083 s if R11 failed to trip, then finally $\mathrm{R} 12$ trips at $2.734 \mathrm{~s}$.

From Figure 7: The Time-Overcurrent Characteristics for AntiClockwise Loop2, the Coordination sequence is as follows: R10 trips at 3.789 s followed by R8 at 4.057 s if R10 failed to trip, then R6 trips at 4.478 s, finally, R7 trips at $6.001 \mathrm{~s}$.

\subsection{Fault on Line7}

From Figure 9: The Time-Overcurrent Characteristics for Clockwise Loop1, the Coordination sequence is as follows: R9 trips at 0.849 s followed by R5 at $1.907 \mathrm{~s}$ if R9 failed to trip, then R1 trips at $2.087 \mathrm{~s}$, finally, R6 trips at $3.112 \mathrm{~s}$.

From Figure 10: The Time-Overcurrent Characteristics for AntiClockwise Loop1, the Coordination sequence is as follows: R4 trips at $0.515 \mathrm{~s}$ followed by $\mathrm{R} 2$ at $0.998 \mathrm{~s}$ if $\mathrm{R} 4$ failed to trip, then R11 trips at $1.232 \mathrm{~s}$, finally, R3 trips at $3.527 \mathrm{~s}$.

From Figure 11: The Time-Overcurrent Characteristics for Clockwise Loop2, the Coordination sequence is as follows: R11 trips at $1.232 \mathrm{~s}$ followed R14 tripping at 27.896s.

From Figure 12: The Time-Overcurrent Characteristics for AntiClockwise Loop2, the Coordination sequence is as follows: R6 trips at 3.112s then R7 trips at $4.071 \mathrm{~s}$ if R6 failed to trip. 


\section{Conclusion}

It can be confirmed from the Time-Overcurrent Characteristics of the Relays that the proposed algorithm has shown improvement in Directional Overcurrent Relay coordination with very fast tripping coordination as displayed in Figure 4 to Figure 12 and has reduced the complexity and painstaking method of manually computing the coordination settings of a multi-sourced microgrid as planned expansion model by the AEDC. The algorithm has proved very satisfactory with improvement on the relay coordination when tested on the modeled network. Hence, this proposed MPSO Algorithm has satisfied the earlier stated aim and objectives of this research work.

\section{References}

[1] Barros, J. A. C. (2008). Development of Cooperative and Coordinated Control For Distributed Generation. University of Porto Journal, 2 (11), 2521-2584.

[2] Bedekar, P. P., Bhide, S. R., \& Kale, V. S. (2009). Optimum Time Coordination Of Over Current Relays In Distribution System Using Big-M (Penalty) Method. WSEAS Trans. on Power Systems, 4 (11), 341-350.

[3] Buigues, G., Dyśko, A., Valverde, V., Zamora, I., \& Fernández, E. (2013). Microgrid Protection: Technical Challenges And Existing Techniques. Paper presented at the International Conference on Renewable Energies and Power Quality (ICREPQ'13), 20 (10), 1242-1254.

[4] Damchi, Y., Mashhadi, H. R., Sadeh, J., \& Bashir, M. (2011). Optimal Coordination Of Directional Overcurrent Relays In A Microgrid System Using A Hybrid Particle Swarm Optimization. Paper presented at the Advanced Power System Automation and Protection (APAP), 2011 International Conference on Power System, 2 (15), 2145-2164.

[5] Geidl, M. (2005). Protection of Power Systems With Distributed Generation: State Of The Art: Citeseer, 53 (12), $42-49$.

[6] Ibe, A., Okedu, E., \& Eng, M. (2009). A Critical Review Of Grid Operations In Nigeria. Pac J Sci Technol, 10 (2), 486490.

[7] Papaspiliotopoulos, V. A., Kurashvili, T., \& Korres, G. N. (2014). Optimal Coordination Of Directional Overcurrent Relays In Distribution Systems With Distributed Generation Based On A Hybrid PSO-LP Algorithm. Paper Presented At The Medpower 2014, 80, 400-423.

[8] Rathinam, A., Sattianadan, D., \& Vijayakumar, K. (2010). Optimal Coordination Of Directional Overcurrent Relays Using Particle Swarm Optimization Technique. International Journal Of Computer Applications (0975-8887), 10 (2).
[9] Vijayakumar, D., \& Nema, R. (2009). Simplified Velocity MPSO For Directional Over Current Relay Coordination. International Journal Of Recent Trends In Engineering, 1 (3), 76-80.

[10] Yang, H., Wen, F., \& Ledwich, G. (2013). Optimal Coordination of Overcurrent Relays in Distribution Systems with Distributed Generators based on Differential Evolution Algorithm. International Transactions on Electrical Energy Systems, 23 (1), 1-12.

\section{Biography}

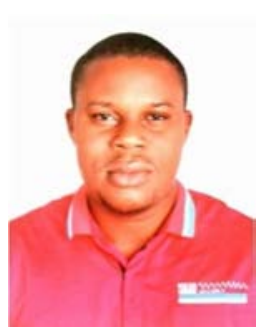

Ukwuoma Pious Akushie received his Bachelor's degree in Electrical \& Computer Engineering from the Federal University of Technology, Minna Nigeria in 2004 and Master's degree in Electrical \& Electronic Engineering (Power System \& Machine Option) from same university in 2017. He is a corporate member of both the Nigerian society of Engineers (NSE) and The Nigeria Institution of Power Engineers (NIPE) and is registered with the Council for the Regulation of Engineering in Nigeria (COREN). His research interest includes Power System Protection, Renewable Energy Integration and Smart Grid Technologies. He is involved in the design and management of Energy Solutions.

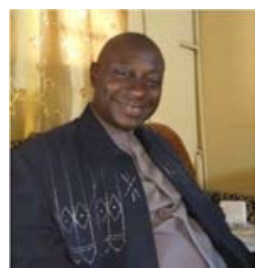

Adegboye Babatunde holds the BEng, MSc and $\mathrm{PhD}$ degrees in Electrical Engineering of the Ahmadu Bello University, Zaria, Nigeria among others. His research interests include Power Systems Reliability and Powerline Communications, where he has lectured and supervised many postgraduate students (Masters and $\mathrm{PhD}$ ). $\mathrm{He}$ is currently a Professor of Electrical Engineering at the Federal University of Technology, Minna Nigeria. Professor Adegboye enjoys reading and listening to classical music.

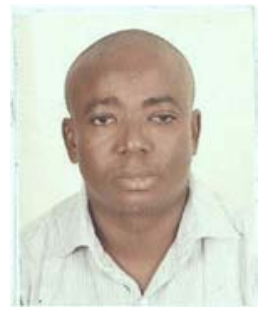

Tsado Jacob obtained his Bachelor of Engineering Degree (B. Eng.) in Electrical \& Computer Engineering from Federal University of Technology Minna, Nigeria in 1998. He also obtained M. Eng and Ph.D in Electrical Power System \& Machine from University of Benin, Benin city, Nigeria in 2001 and 2007 respectively. $\mathrm{He}$ is an Associate Professor and the current Head of Department for Electrical and Electronics Engineering. He has authored and co-authored quite number of published journal papers and conference proceedings. His research area is power system and energy studies with special interest in Protection Schemes. 